\title{
Project Management In Universities: The Institutional Aspect
}

Agata Klaus-Rosińska, Wroclaw University of Technology, Poland

Anna Zabłocka-Kluczka, Wroclaw University of Technology, Poland

\begin{abstract}
The complementary aims of this manuscript are to describe the issue of project management in universities and to present proposals that may improve that area within selected institutions. The improvements are meant to enable project management at the university level in a coherent and coordinated way. These proposals were derived from experiential research carried out by the authors at a Polish university.
\end{abstract}

Keywords: Project Management; Institutional Aspect

\section{INTRODUCTION}

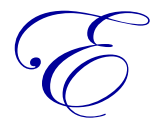

fficient project management, which results in the achievement of desired goals within a specified budget and time frame and in accordance with accepted quality standards, requires careful planning and control. This is especially true for institutions whose activities are project-based, like universities. A close examination of university-based projects will reveal several imperfections and difficulties that hamper the organization's ability to successfully realize the goals of the project. These barriers to success include, but are not limited to, the following:

\footnotetext{
- $\quad$ rigid organizational structures that are unsuitable for the implementation of projects

- $\quad$ lack of formal authority for projects and their managers

- $\quad$ poor internal and external communication

- $\quad$ inadequate or overly formalized project documentation

- $\quad$ inadequate or poorly designed mechanisms of project quality management

- $\quad$ lack of qualified project personnel
}

The above-mentioned factors are similar to those which may cause the project management to fail in any organization. I. Avots, for example, indicates factors such as 'inadequate basis for project, wrong person as project manager, top management unsupportive, inadequately defined tasks, lack of project management techniques, management techniques mis-used, project closedown not planned, and lack of commitment to project' (Avots, 1969).

It is widely accepted that barriers indicated for universities constrain the planning and realization of university-based projects, but they are rarely systematically dealt with. It is therefore important to develop effective project management systems for universities to facilitate the organization of projects, the reporting of their progress, and, ultimately, their successful conclusion. Specialists of project management suggest that successful project management requires, among others, planning with a commitment to complete the project, careful appointment of a skilled project manager, spending time to define the project adequately, correctly planning the activities in the project, and ensuring correct and adequate information flows (Camilleri, 2011; Munns \& Bjeirmi, 1996). Improvements to project management in universities should be implemented at both the entity level (i.e., university level) (IDS Scheer, 2010; Grzech et al., 2011) and the level of the project itself (i.e., project cost management (Espinasse, 2011; Ratnatunga \& Waldmann, 2010), project time management (Naveh, 2006), and project risk management (Wageman, 2004; Wang et al., 2010). Given this, the objective of this paper is twofold. First, it will 
present institutional solutions for project management in a Polish university. Second, these proposals will be evaluated in terms of their impact on the faults identified above.

\section{The Institutional Aspect Of Project Management}

There are three primary aspects to project management (Trocki, Grucza, \& Ogonek, 2004) - the functional, the institutional (otherwise known as the organizational), and the personal aspects. The functional aspect is related to the fundamental processes of project management, which include initiation, planning, implementation, closure, and control of projects. The institutional aspects of project management raise concerns regarding the project location within a specified organizational structure. Personal aspects are related to problems regarding the selection and direction of project personnel.

Generally, institutions employ a variety of organizational structures which range from largely linear in kind to a complex matrix organizational structure. The organizational structure chosen to carry out projects is contingent on two things: 1) the importance and specialization of project and 2) the extent to which the project is complex and innovative (Trocki et al., 2004). As a general rule, the higher the position of the project in the organization (as evidenced by its importance and specialization) and the greater the extent to which it is autonomous (as evidenced by the extent to which it is complex and innovative), the more closely the structure should resemble that of a pure project organization. The relationship is illustrated in Figure 1.

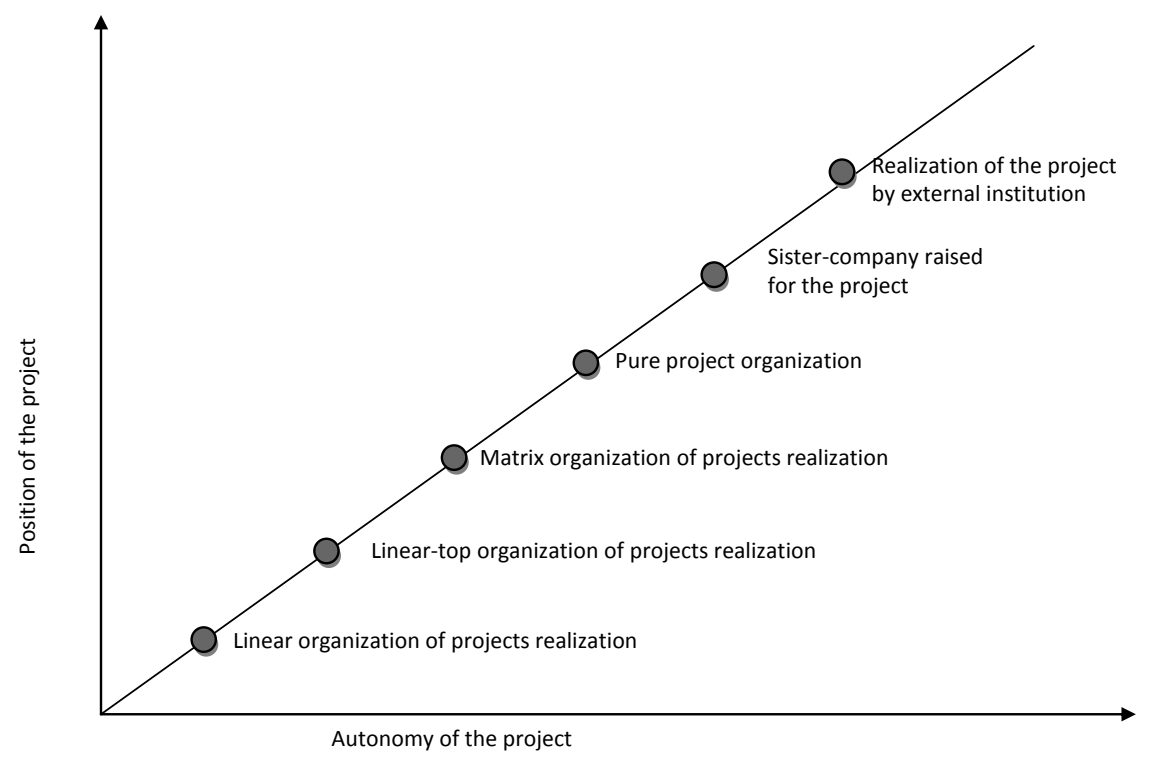

Figure 1: Structure Of The Organization Managed By The Projects (Trocki et al., 2004)

The least advanced organizational structure is the linear organization. For projects within linear organizations, units are located on the lower levels of management within the organizational divisions. They are subordinate to the management personnel who oversee these divisions. The quality of projects that are carried out in linear organizations depends on the type of linear structure implemented - functional, object, or territorial.

When a project requires attention beyond the range of one division, as is often the case in linear structures, it may encounter coordination problems. Managers of the divisions in which the projects are being conducted have little power to coordinate their interaction and cooperation. These powers are held by top management, which typically employs the use of special (staff) units that report to management directly. A second type of organizational structure is referred to as the linear-top organization. It is worth noting that in this structure, the special (staff) units perform planning, coordination, and control functions, but strategic and decisional powers are retained by top management. 
In some instances, project management requires extra dimensions of coordination and communication. In these cases, the project can be best served by a matrix-like organizational structure. This structure is based on two dimensions at the top management level - the nature of the project itself and one of the traditional types of coordination (i.e., functional, object, or territorial). Although a matrix structure reduces the number of management levels within the organization, it also necessitates complex coordination decisions between specific unit managers. Matrix structures are best used to implement projects in very large companies with multi-dimensional coordinate activities as well as in small and medium-sized enterprises carrying out a large number of diverse projects.

Another structure, in terms of organizational maturity and project implementation, is called pure project organization. It excludes project tasks from the organizational structure and creates a separate structure responsible for the project. Pure project organizations are typically comprised of the staff from various departments of the existing institutional structure. It offers good control of project progress, affects decisions fundamental to the project and releases top management from the burden of coordinating disruptive activities. The primary disadvantage of the pure project organizational structure is its tendency to make cooperation between separate units of the organizational structure difficult. This kind of organizational structure is best used for autonomous projects related to extant institutional activity.

A specific way in which a project's goals can be realized is through the use of a sister company, which is employed for the duration of the project. The sister company is a subtype of the pure project organization and is appropriate for high-risk projects involving a significant amount of cash.

When the institution is unable to fulfill the project's needs, it can outsource it to an external company. Of course, in this case it is difficult to discuss maturity and advancement of an institution with respect to project management (Trocki et al., 2004).

Selection of an effective organizational structure to carry out projects is a difficult endeavor, particularly when the projects require a longer period of time to be completed. As such, the choice of an organization's structure is determined by several factors which include, but are not limited to, institutional size, degree of functional complexity, the diversity of projects taken on by the institution, the availability of appropriate facilities, and the possession of pertinent knowledge or other resources.

This manuscript presents institutional proposals to improve project management in a Polish university. These proposals include converting university management to a process-based approach and the incorporation of appropriate organizational structures on the identified processes. The organizational characteristics of the existing project management in the case university will be described in the next section, followed by an exploration of the changes in the institutional aspect.

\section{Description Of The Organizational Solutions In The Area Of Project Management Existing In The Chosen University}

The issue of organizational development in the context of integrated project management in universities will be presented using the case of a university in Poland (henceforth, the University) as an example. The University handles hundreds of research projects annually that receive funding from several sources.

Solutions for project management should be clearly reflected in the context of the University; hence, their explication will be preceded by a brief description of the University's assumptions related to project management. Research carried out by two independent teams - an external company analyzing the processes of the University (2010) and an internal team established to improve project management $(2011)^{1}$ - concluded that the University's current system does not satisfactorily integrate project management into its practices. These evaluations further concluded that there was an urgent need to introduce changes aimed at clarifying the current approach to project management.

\footnotetext{
${ }^{1}$ More results of this work are described in the reports: "Analysis and optimization of core and supporting processes of the activities of the University" (Report I, by IDS Scheer), "The concept of Project Management Center of the University" (Report II, Authors: Aleksandra Grzech, Agata Klaus-Rosińska, Rafał Pawełczak, Anna Zabłocka-Kluczka).
} 
Existing solutions at the University are resultant from a long evolution of solutions used to support research projects. The University has handled an array of projects from the mid-1990s through the present. To support these projects, The Research Department was established. In addition, Polish accession to the European Union introduced the possibility of further monetary support, necessitating the establishment of the Office of Grants and European Funds, which has since been absorbed by the Department of Monitoring and Project Management.

Given this, activities in the University related to project management are handled by the two business units - The Department of Research and the Department of Monitoring and Project Management (see Figure 2). These units are subordinate to two different Vice-Rectors and operate under the auspices of the Department of Finances, Department of Human Resources Management, and the Contracts Department.

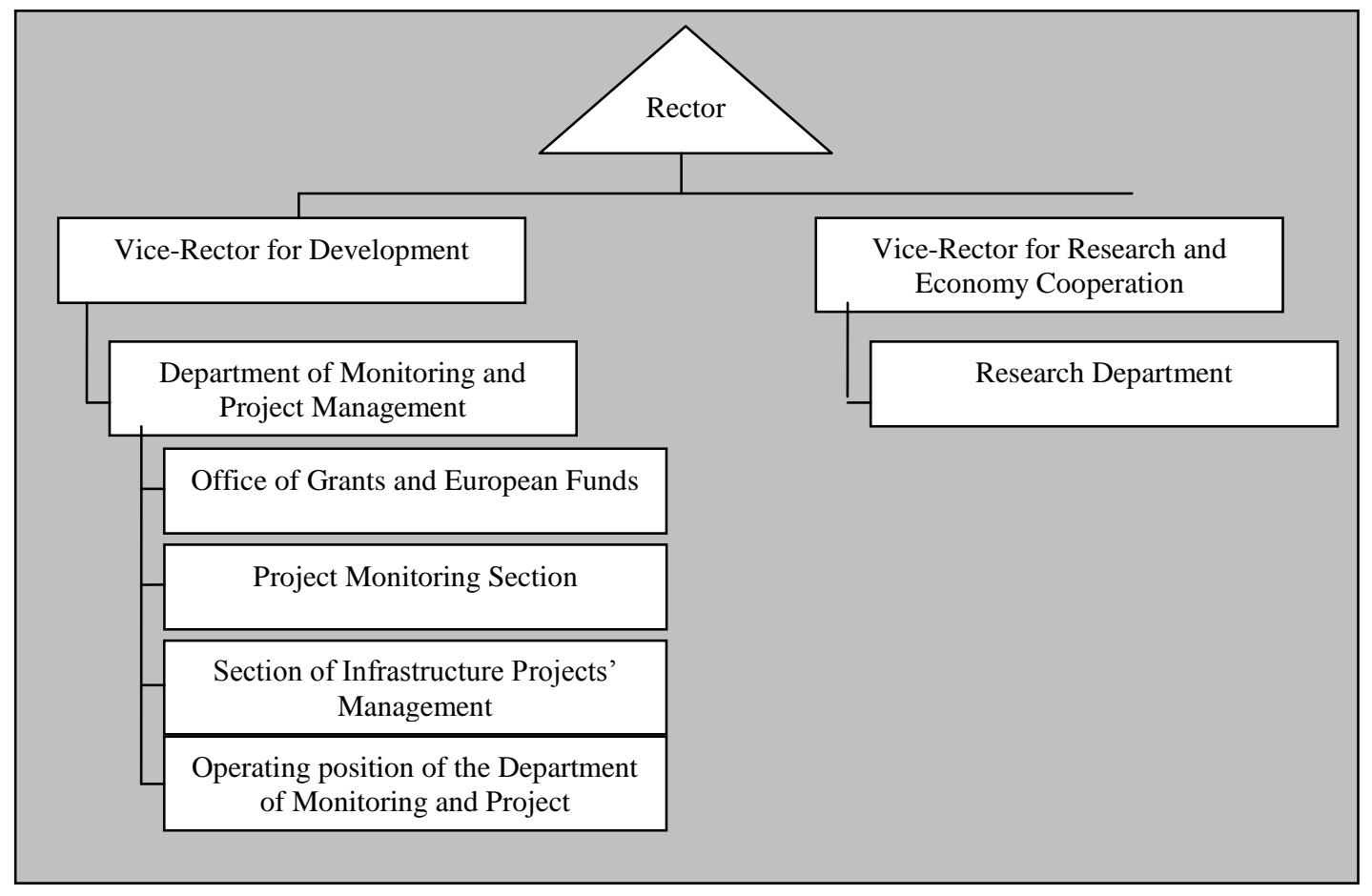

Figure 2: Part Of The Organizational Structure Of The University Presenting Units Directly Involved In The Preparation And Implementation Of Projects (Grzech et al., 2011)

The range of tasks to be performed by individual departments and sections involved with the processes of preparing and implementing projects at the University is shown in Table 1. 
Table 1: The Tasks Performed In The Project Management Area

Of The University (Produced By The Author Based On Internal Documents Of The University)

\begin{tabular}{|c|c|}
\hline $\begin{array}{c}\text { Name Of } \\
\text { Organizational Unit }\end{array}$ & The Range Of Tasks \\
\hline Research Department & $\begin{array}{l}\text { 1. Coordination of activities related to submitting for funding of research under: } \\
\text { a. statutory research; } \\
\text { b. individual research projects; } \\
\text { c. cooperation with foreign countries in accordance with governmental agreements, programs, } \\
\text { or protocols; and } \\
\text { d. special test equipment, special research programs, and scientific networks. } \\
\text { 2. Organizing activities related to the formal and substantive settlement of statutory and individual } \\
\text { research. } \\
\text { 3. Coordinating activities related to applying for allocation of funds from the Foundation for Polish } \\
\text { Science. } \\
\text { 4. Coordinating activities related to applying for allocation of funds from the National Center for } \\
\text { 5. Orearch and Development. } \\
\text { 6. Initiating work on the development of research in the University. } \\
\text { 7. Cooperating with the state administration and local government. } \\
\text { 8. Searching for extra funding (other than budgetary) opportunities for research. } \\
\text { 9. Coordinating activities related to creating and updating a database of solutions and results of } \\
\text { scientific research works planned for commercialization and lists of experts in various fields. } \\
\text { 10. Formal and legal support for the negotiation, preparation, signing, execution, and settlement of } \\
\text { contracts for the commercialization of research results with national and international businesses } \\
\text { and administrations. } \\
\text { 11. Coordinating and operating formal and legal agreements concerning the implementation of } \\
\text { research contracts, consortium, and cooperation agreements on research. } \\
\text { 12. Advisory and Consultative activity. }\end{array}$ \\
\hline $\begin{array}{l}\text { Department of } \\
\text { Monitoring and } \\
\text { Project Management }\end{array}$ & $\begin{array}{l}\text { 1. Information and advice on obtaining funds from European Funds and assistance in the } \\
\text { preparation of project proposals. } \\
\text { 2. Assessment and monitoring of projects financed from European Funds and realized at the } \\
\text { University during their implementation and sustainability. } \\
\text { 3. Management of infrastructure projects financed from European Funds and other entrusted } \\
\text { sources for realization by the Rector. } \\
\text { 4. Preparing periodic reports on the implementation of projects financed from European Funds for } \\
\text { 5. De university authorities. } \\
\text { 6. Maintaining databases on University projects financed from European Funds. }\end{array}$ \\
\hline \multicolumn{2}{|c|}{ The Tasks Of Different Sections And Positions Within The Department Of Monitoring And Project Management Include: } \\
\hline $\begin{array}{l}\text { Office of Grants and } \\
\text { European Funds }\end{array}$ & $\begin{array}{l}\text { 1. Dissemination of information about international programs, research grants, and research } \\
\text { structural funds. } \\
\text { 2. Advice, consultancy, and assistance in preparing proposals. } \\
\text { 3. Act as local contact point for the framework programs. } \\
\text { 4. Supervision of the preparation and implementation of projects financed by the EU under the } \\
\text { framework programs, the EEA Financial Mechanism, Norwegian Financial Mechanism, and the } \\
\text { other authorities commissioned by the Rector. } \\
\text { 5. Keeping a database of foreign research projects (registration of applications and contracts). }\end{array}$ \\
\hline
\end{tabular}


(Table 1 continued)

\begin{tabular}{|c|c|}
\hline $\begin{array}{l}\text { Project Monitoring } \\
\text { Section }\end{array}$ & $\begin{array}{l}\text { 1. Economic and financial analysis of grant applications for compliance with the guidelines of } \\
\text { 2. Supervision over the process of signing grant contracts and annexes in the projects. } \\
\text { 3. Verification of periodic applications for payment and reporting information. } \\
\text { 4. Monitoring of the implementation of projects. } \\
\text { 5. Taking steps to execute the audit recommendations. } \\
\text { 6. Conducting all activities (proceedings) supervision in relation to ongoing projects. }\end{array}$ \\
\hline $\begin{array}{l}\text { Section of } \\
\text { Infrastructure } \\
\text { Projects' } \\
\text { Management }\end{array}$ & $\begin{array}{l}\text { 1. Implementation of the projects entrusted by the Rector in accordance with the requirements of } \\
\text { managing institutions of the structural funds. } \\
\text { 2. Acceptance of the incurred expenditures and proper settlement of projects until completion. } \\
\text { 3. Preparing applications of payment, statements and reports of the implementation of projects, and } \\
\text { other documents in this regard. } \\
\text { 4. Participation in the development of internal procedures for the realization of investment projects. } \\
\text { 6. Realization of activities related to information and promotion of investment projects. } \\
\text { 7. Therming about the possibility of obtaining funds for investment projects. }\end{array}$ \\
\hline $\begin{array}{l}\text { Operating position of } \\
\text { the Department of } \\
\text { Monitoring and } \\
\text { Project Management }\end{array}$ & $\begin{array}{l}\text { 1. Ensuring proper circulation of documents and information within the department and between } \\
\text { the department and other organizational units of the University. } \\
\text { 2. Providing professional administrative services to the department. } \\
\text { 3. Assistance in the preparation of reports, statements, presentations, etc. }\end{array}$ \\
\hline
\end{tabular}

Creating the described structures was dictated by the need to support executors of the projects rather than the preference to coordinate project activities at the University. For the preparation and implementation of scientific and educational projects are responsible researchers directly interested in their implementation, while for the implementation of infrastructure projects are responsible employees of central or departmental administration (accordingly to the scope of the project). In each case, the Rector appoints a Project Manager and/or Project Coordinator who is responsible for the project's preparation and implementation. In particular, the Project Coordinator is responsible for initiating a project, determining the scope of work for its completion, dividing the work of the consortium, preparing application documents, creating a team, scheduling, budgeting, and opening a bank account. Simultaneously, he is responsible for the financial and technical clearance of the project and for the preparation of the documents necessary for its implementation. Of particular importance to this end are the interim and final reports related to payments. In the case of external control, the Project Coordinator makes arrangements for inspection, prepares documents for inspection, and follows up to resolve discrepancies identified by the inspection (Grzech, Klaus-Rosinska, Pawelczak, \& Zablocka-Kluczka, 2011).

In the case of scientific projects related to research and education, the project coordinators are academics who are substantively competent and prepared to meet the academic needs of the project. However, academic project coordinators are often inexperienced when it comes to administrative tasks. In performing such tasks, they are supported by the Department of Research, the Department of Monitoring and Project Management, or other administrative units at the University. At the initial stages of the projects, the activities are primarily geared towards seeking funding for research projects and preparing the documentation to secure it. At the implementation stage of the project, the activities are coordinated and supported by the appropriate department. These activities chiefly include the supervision of the financial and substantive tenets of the projects. More specifically, the activities of the departments are different; the Department of Monitoring and Project Management is more concerned with monitoring the project budgets, the schedules, and the achievements of project measures. In addition, the Department of Monitoring and Project Management is responsible for documenting the project to its completion. The Department's ability to perform these tasks is tempered to the extent that it is subjected to restrictive guidelines for projects financed from EU funds.

Support for research projects by existing structures of the University is primarily provided at the operational level of project management. In contrast, little is done for the management of projects at the strategic level. First, there is no project portfolio planning at the strategic level. There is no mechanism by which research projects can be prioritized, so projects are undertaken in various research areas with no clear direction for the University's development in a given area. This may lead to a positive outcome in the form of a diverse multifaceted research portfolio; however, it can also negatively impact the reputation of the University. The focus of resources on 
a few prioritized research areas may allow the University to gain advantage over other research centers in the chosen field of research. In addition, the strategic planning of projects should account for not only the substantive aspect but also the financial aspect. By agreeing to take on a project, the University agrees to take on a commitment of financial support (e.g., the conditional provision of loans) which can pose a significant risk to financial safety.

Currently, there are no unified standards for the operationalization of projects. The power structure between the two departments and other administrative units may result in the execution of the same processes in very different ways, thus reflecting different standards of work. Further, there is no mechanism by which experiences and best practices can be communicated between departments. Internal organizational solutions are not tailored to carry out specific projects. The regulations are based on the respective department's practices, but do not create a comprehensive and coherent system for project management.

These weaknesses are not the only deficiencies inherent in the University's current practices. Other weaknesses include inadequate administrative support, lack of support for the negotiation and drawing up of contracts and intellectual property protection, lack of tools to support project implementation, lack of a database of projects, lack of sustainability, and lack of advisory points for potential managers/project coordinators ${ }^{2}$. Although the number of identifiable deficiencies in the University's current practices are many, the chief weaknesses of the current system are the lack of unified standards to approach project management and the failure to incorporate a coherent strategic approach to extant problems.

\section{Description Of The New Organizational Solutions In The University Including Tasks And Responsibilities For Project Management}

These identified shortcomings have led to the systematic evolution of project management solutions. This evolution could lead to the elimination of these pointed weaknesses. It has coincided with the reorganization of the University and the transition from functional management to process management. According to the reconstruction of the University's management system, proposals for new solutions in the area of project management will be based on process approaches as well.

Thus, the starting point for designing specific solutions was a mapping of project management processes carried out at the University. This map presents all the activities at the strategic and operational levels related to planning, coordination, and supervision of all projects, regardless of their funding sources or implementation protocols (see Figure 3). In this process, three basic phases of project management were identified:

- $\quad$ The projects planning phase, including two sub-processes:

$\circ \quad$ drafting

$\circ \quad$ initiating the project

- $\quad$ The projects implementation and closure phase, including the following sub-processes:

- realization of substantive and administrative tasks in various stages of the project

$\circ \quad$ the current management state of the project

$\circ \quad$ verification of the results obtained under a given stage

$\circ \quad$ project monitoring

$\circ \quad$ support for external and internal controls and audits of the project

- closing a project

- The supervision of the project sustainability phase, including:

$\circ \quad$ supervising the archiving of project documentation

$\circ \quad$ supervising the implementation of results indicators

○ supervising the sustainability of project outcomes (Grzech et al., 2011)

Project management cannot be performed in isolation from other support processes of the University. Among these support processes, the most important are university management, financial management, and human resource management. Relationships of the project management process with other processes may not be the most

\footnotetext{
${ }^{2}$ More are described in the report (Grzech et al., 2011).
} 
conspicuous, but are nonetheless vital to the successful management of projects at the operational and strategic levels.

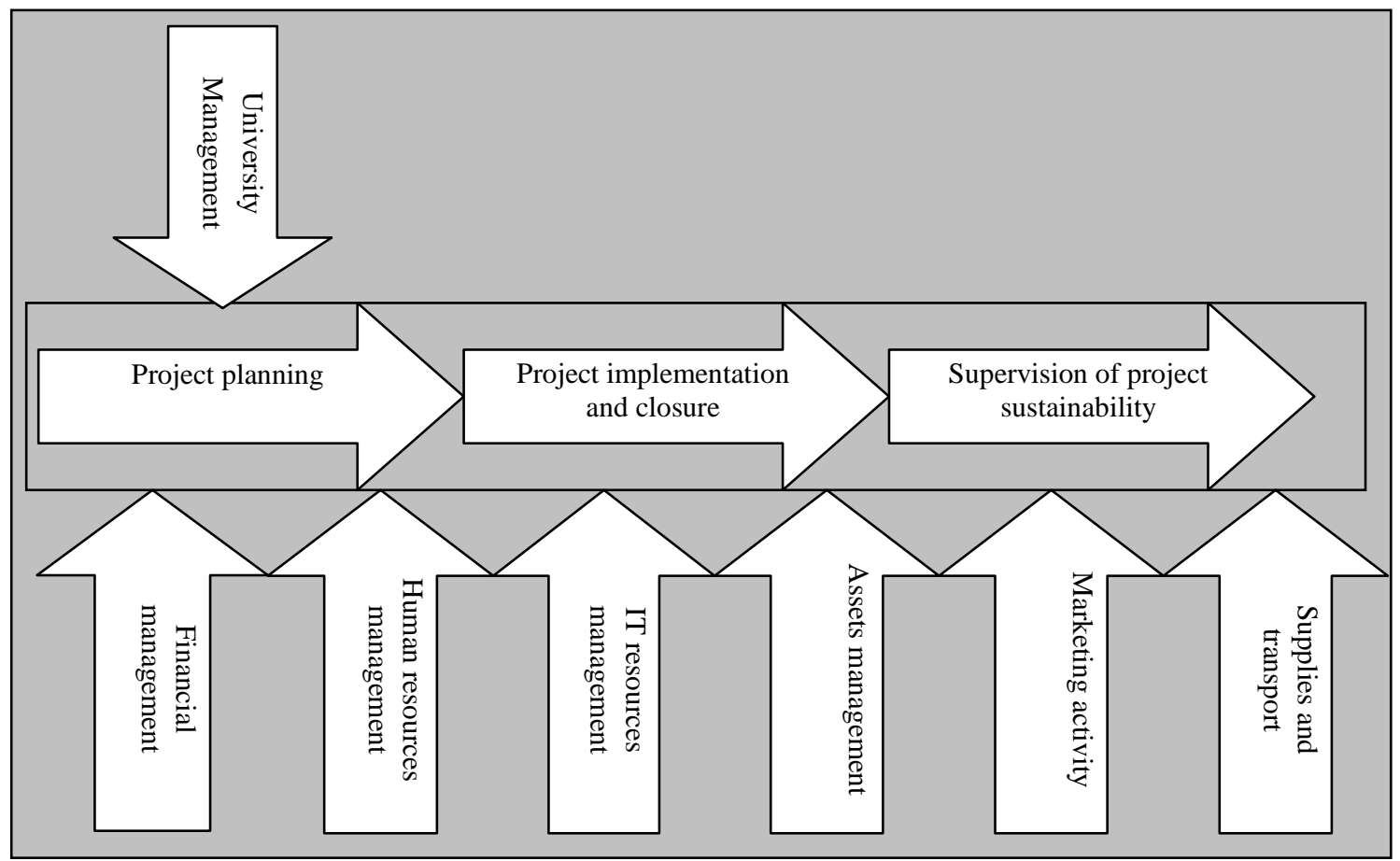

Figure 3: General Map Of The Project Management Process (Grzech et al., 2011)

The overarching entity encompassing the entire project management system would be a Project Management Centre, which would bring together activities in the areas of project planning, coordinating, and monitoring and would provide mediation services related to project decisions as well. The Project Management Centre can be understood as PMO (Project Management Office) which is a formal layer of control between top management and project management within organization (Kerzner, 2003; Liu and Yetton, 2007). Because the shapes and roles of PMO's functions vary according to the context within they are incorporated (Aubrey et. al., 2010), authors of presented solutions decided to use a different name. The decision is based on the research conducted by S. Pemsel and A. Wiewiora who claim that the complexity and variety of PMOs have evidently resulted in a number of interpretations of what a PMO actually is and should do, both in practice and in research terms (Pemsel \& Wiewiora, 2013).

Organizational units performing supporting or managerial functions should be in contact with the Project Coordinator and/or the Project Manager through the Project Management Centre. However, during crises, direct contact between the Project Coordinator and/or the Project Manager and the above-pointed university units would also be possible.

The proposed organizational solutions are the result of a project management conceptualization operationalized by the University. They limit the flexibility of organizational behavior and define the roles of managers and others involved in project management. The presented solutions are pertinent to the whole organization (project management process) rather than individual projects. As such, their operationalization remains consistent with other processes used by the University. Figure 4 presents the internal structure of the proposed Project Management Centre in the synthetic approach. For each of the three main phases of the project management process, the establishment of organizational units responsible for the tasks in these phases has been provided. Thus, the structure of the Centre is based on three offices: 
- $\quad$ The Office of Projects Planning: responsible for widely understood preparation of the projects (i.e., the projects planning phase)

- $\quad$ The Office of Supporting the Projects Implementation and Closure: responsible for project implementation and closure (i.e., the projects implementation and closure phase)

- The Office of Supervision of the Projects Sustainability: responsible for the procedure after the projects' completion (i.e., the supervision of the project sustainability phase (Grzech et al., 2011)

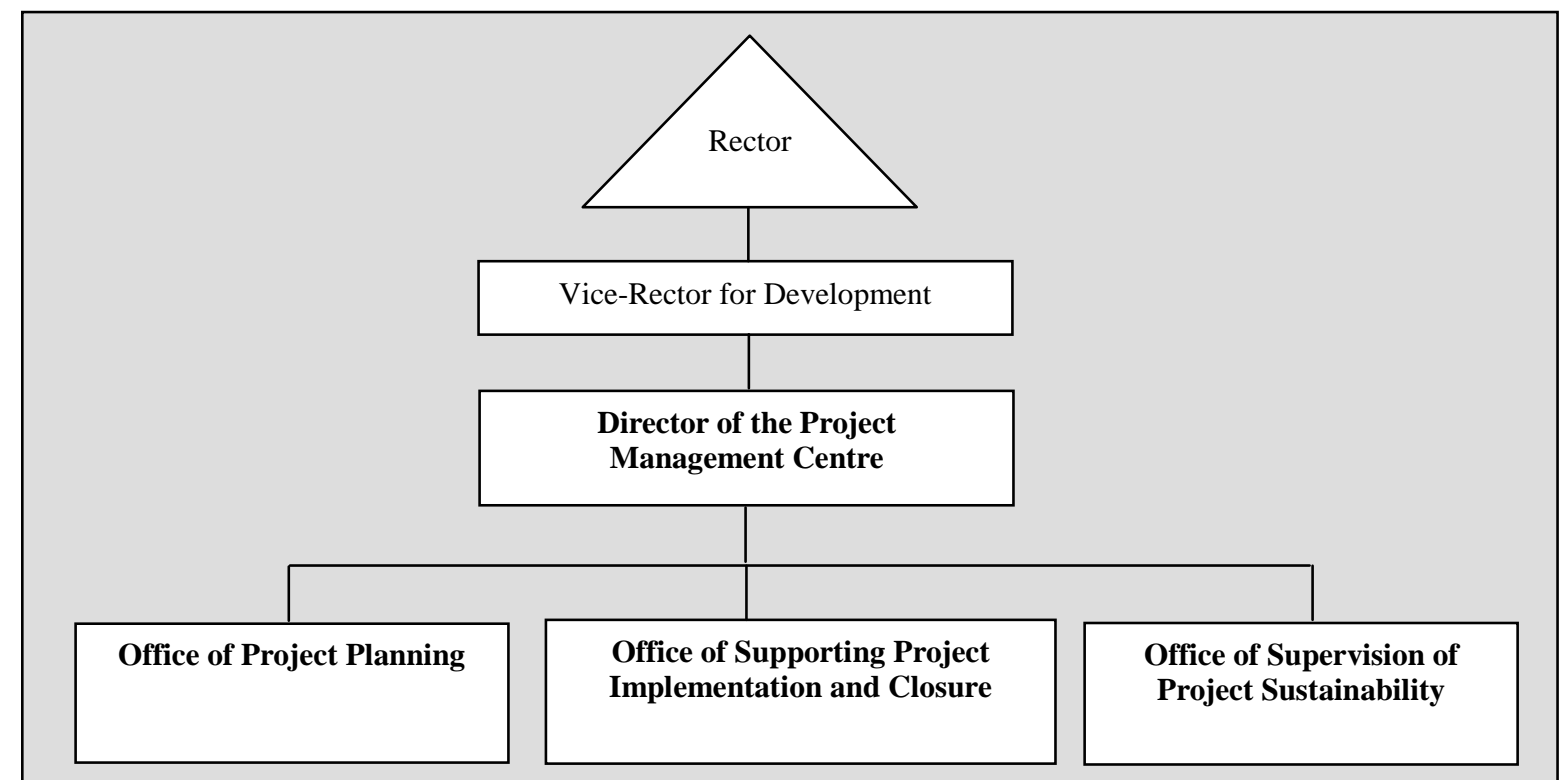

Figure 4: Suggested Internal Structure Of The Project Management Centre - Synthetic Approach (Grzech et al., 2011)

The strategic role of the Project Management Centre (PMC) is the creation, development, and continuous improvement of project management standards in the University and the provision of key information necessary for the process of strategic projects management.

At the operational level, the main role of the Project Management Centre is to provide administrative support to potential and actual executors of projects and ensure that the developed standards would be followed during the implementation of particular projects. Specifically, each office should carry out informational, advisory, coordination, regulating, monitoring, promotional, and educational functions. Their synthetic characteristics in a cross-section of each office are presented in the Table 2. 
Table 2: Synthetic Characteristics Of The Functions Of The Particular Offices Of PMC (Grzech et al., 2011)

\begin{tabular}{|c|c|c|}
\hline Unit & Function & Synthetic Description Of The Function \\
\hline \multirow{4}{*}{$\begin{array}{l}\text { Office of Project } \\
\text { Planning }\end{array}$} & Informational & $\begin{array}{l}\text { Providing information to potential implementers of projects } \\
\text { Providing information for the purpose of project management to the university } \\
\text { authorities }\end{array}$ \\
\hline & Advisory & $\begin{array}{l}\text { Supporting the preparation of projects and contract signing in collaboration with } \\
\text { other universities }\end{array}$ \\
\hline & Coordination & $\begin{array}{l}\text { Coordination of the work of university-wide task forces appointed to deal with } \\
\text { special problems arising in the project planning phase }\end{array}$ \\
\hline & Educational & Training for project managers \\
\hline \multirow{6}{*}{$\begin{array}{l}\text { Office of Supporting } \\
\text { Project } \\
\text { Implementation and } \\
\text { Closure }\end{array}$} & Control & Supervising and monitoring the implementation and closing of projects \\
\hline & Advisory & $\begin{array}{l}\text { Counseling in collaboration with the other university units in resolving the } \\
\text { problems arising during the project implementation and closure phases }\end{array}$ \\
\hline & Coordination & $\begin{array}{l}\text { Coordination of internal and external inspections and audits } \\
\text { Coordination of university-wide project teams created to solve specific problems } \\
\text { arising at the stage of implementation and closure of projects }\end{array}$ \\
\hline & Promotional & Supporting the promotional activities especially in structural projects \\
\hline & Informational & $\begin{array}{l}\text { Sharing the best practices with the coordinators of the projects, reporting the } \\
\text { project activities at the University }\end{array}$ \\
\hline & Educational & Training for project managers \\
\hline \multirow{4}{*}{$\begin{array}{l}\text { Office of Supervision } \\
\text { of Project } \\
\text { Sustainability }\end{array}$} & Coordination & $\begin{array}{l}\text { Coordinating the process of archiving the documents } \\
\text { Coordinating the process of commercialization of the project results }\end{array}$ \\
\hline & Control & $\begin{array}{l}\text { Supervising of the implementation of indicators to ensure the sustainability of } \\
\text { project results }\end{array}$ \\
\hline & Informational & $\begin{array}{l}\text { Information activities concerning the possibility of commercializing the project } \\
\text { results } \\
\text { Sharing the best practices for commercializing the project results }\end{array}$ \\
\hline & Educational & Training for project managers \\
\hline
\end{tabular}

Because of the diversity of projects handled at the University and therefore the variety of requirements to which the University must adhere to (at both the planning and implementation stages of these projects), it is reasonable to train the staff to prepare grant applications and operate various types of projects. According to these criteria for differentiating the internal structure of the various offices, the type/nature of the project was proposed. The proposed organizational structure is presented in Figure 5. 


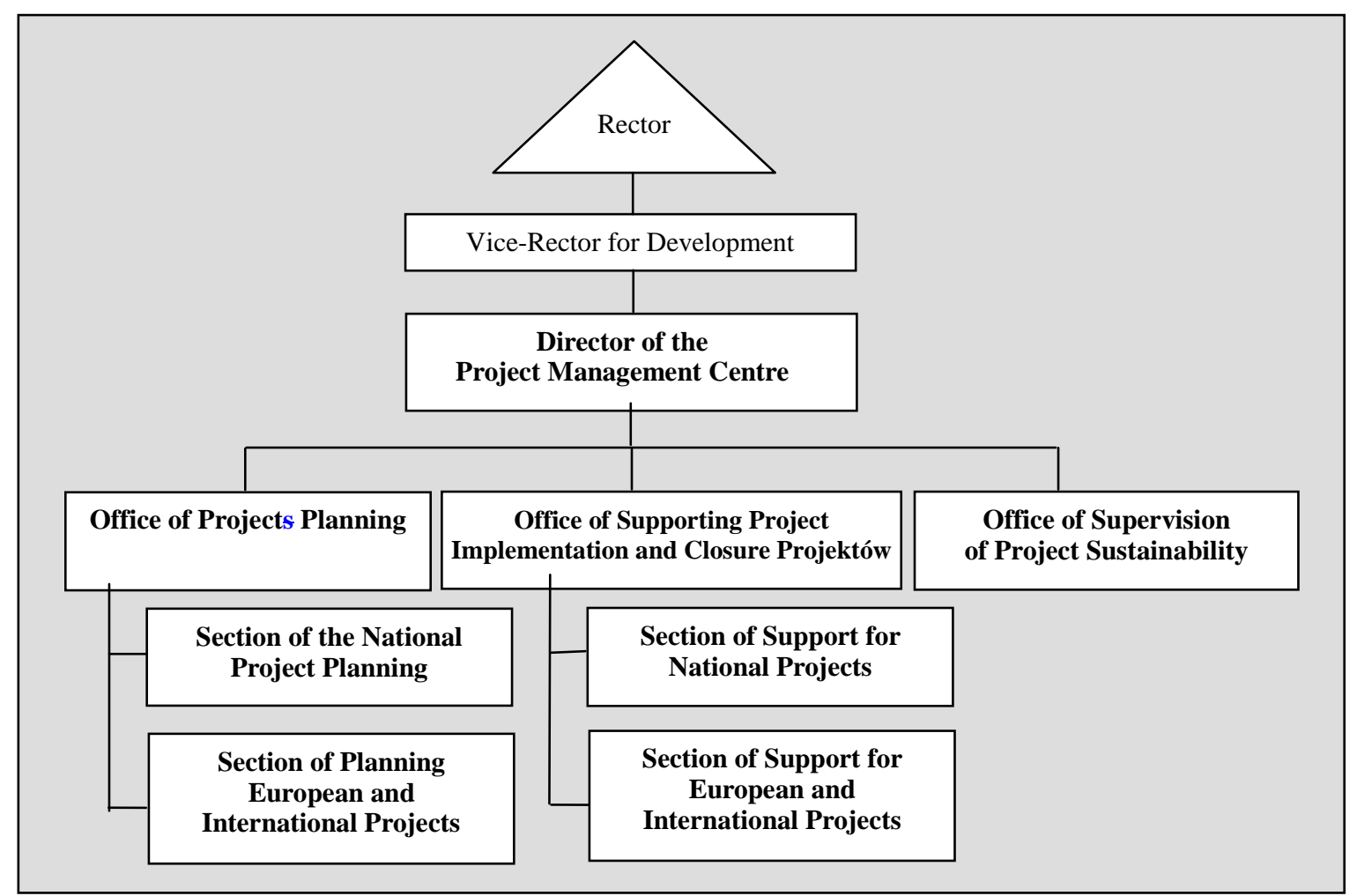

Figure 5: Suggested Internal Structure Of The Project Management Centre - Specification (Grzech et al., 2011)

Employees of particular departments may be involved in one or more projects at multiple university departments or may be subordinate to the central administration. To avoid confusion in the management's responsibilities, it seems reasonable to assign supervisory functions on individual projects to the specific staff during the planning section, the implementation stage, and project culmination. Further, it would be prudent to leave the decision in this area to the managers of particular offices. Regardless of suggested training protocols, all employees of the Project Planning Office should be able to provide basic information on how to carry out the projects, find funding sources, offer program guidelines, and, if necessary, direct interested persons to the appropriate specialist.

In addition to these organizational units, functioning in a routine manner to solve standard problems or specific tasks in project management can be performed by committees and/or task forces consisting of local or university authorities. With the establishment of each team, its creator must indicate the tasks assigned to it for execution. This approach makes for a more flexible project management structure, which facilitates the use of specialized knowledge by university staff.

The general tasks of the Project Management Centre can be divided at the strategic and operational levels. The strategic tasks include the following:

- $\quad$ coordinating the management of research, investment, and educational projects

- $\quad$ creation and improvement of standards and procedures for project management

- $\quad$ management of strategic projects of investment entrusted by the Rector

- requesting the Rector for strategic decisions taken in connection with irregularities detected during the implementation phase of the project (e.g., change the Project Coordinator, the termination of the grant)

- $\quad$ providing information for the project management use (including planning for a portfolio of projects) to the University authorities (Grzech et al., 2011)

Operational tasks of the Centre are presented by particular offices. The tasks of The Office of Projects Planning should be: 
- $\quad$ informing about possibilities of raising funds for research, investment, and educational projects

- $\quad$ advising on the choice of funding sources

- $\quad$ assisting in preparing grant applications and their verification, particularly coordination of university-wide activities including:

$\circ \quad$ selecting the members of the project team, creating plans for recruitment, and selection of employment forms

- creating budgets and preparing project schedules and assessing the eligibility of costs (in structural projects)

$\circ \quad$ resolving the law issues

- $\quad$ setting up of plans for purchases in accordance with public procurement law

- $\quad$ support for the negotiation of foreign and domestic contracts and in the drafting and signing of grant agreements

- $\quad$ recording of submitted and accepted applications for funds and contracts signed

- $\quad$ providing education and guidance for project coordinators and project managers in planning of the projects

- $\quad$ creating procedures and norms of internal documents

- $\quad$ providing information on the project management to appropriate University authorities (statistics and internal reporting)

- $\quad$ planning and preparing strategic projects of investment entrusted by the Rector

The tasks of The Office of Supporting the Projects Implementation and Closure should include:

- $\quad$ monitoring key parameters of the research, investment, and educational projects ${ }^{3}$, including:

$\circ \quad$ reviewing the information on the progress of a project

$\circ \quad$ formalizing and financially assessing of the projects for compliance with the application forms and organizational standards

$0 \quad$ identifying possible discrepancies in the project

- establishing the necessity of giving opinions on irregularities found by the independent experts

$\circ \quad$ informing appropriate university authorities about irregularities in the project

- supervising the removal of irregularities

- conducting formal review and registration of applications for payment and periodic reports

- $\quad$ organizing emergency response

- $\quad$ developing appendices of project documents (contracts with timetables)

- $\quad$ advising on the implementation of purchasing procedures, making settlements, and promoting projects

- $\quad$ advising on and arranging the scheme of project documents organized in accordance with the requirements of the university

- $\quad$ collaborating with other university units to solve specific problems in the areas of employment, cost accounting, public procurement law, etc. that arise during the implementation of projects

- coordinating internal and external controls and audits, including the monitoring of project evaluations issued by the inspection, records of any abnormalities, and supervising their removal

- $\quad$ coordinating academic support units in the process of closing out the project

- $\quad$ reporting descriptive statistics of the project

- developing internal procedures and document norms useful for the implementation project closure phases

- $\quad$ educating project personnel, including sharing of the best practices and interpretation of the provisions with the coordinators of the projects

- $\quad$ implementing strategic investment projects undertaken at the request of the Rector Finally, the Office of Supervision of the Projects should:

- $\quad$ supervise the archiving of documents by the project Coordinator in accordance with the requirements of the university

- $\quad$ gather projects sustainability plans

- $\quad$ verify reports and indicators of sustainability and save the results of those actions on the computer system

\footnotetext{
${ }^{3}$ Substantive, formal and financial responsibility for the project belongs to its Coordinator. The existence of the Project Management Center in no way relieves him of this responsibility.
} 
- $\quad$ supervise the active use of equipment purchased in the projects and other assets generated as a result of their implementation

- $\quad$ supervise activities related to the commercialization of research results and their coordination

- $\quad$ organize training and informational activities concerning the possibility of commercializing the results of projects, sharing the best practices in the areas mentioned above

- $\quad$ produce reports and statistical studies for projects under the supervision of their sustainability

- $\quad$ provide information on completed projects, the results achieved in the projects, the current state of implementation of indicators, etc. (Grzech at al., 2011)

\section{SUMMARY}

The solutions proposed by the authors are a response to the identified deficiencies in not only the case university, but also other universities. These solutions provide guidelines for standardizing project management processes, benchmarking using measures, and providing greater transparency of the departments' activities and the ability to optimize the university operating costs. However, it should be stressed that the proposals discussed here are not "advanced" in terms of organization's maturity. In instances where a different university is at a different level of organizational maturity in terms of its project management, other organizational structures may prove optimal.

\section{AUTHOR INFORMATION}

Anna Zabłocka-Kluczka, Ph. D. Eng., is Associate Professor at the Institute of Organization and Management, Faculty of Computer Science and Management, Wroclaw University of Technology (Poland). Dr. Zabłocka-Kluczka received her Ph.D. in management sciences at Wroclaw University of Technology. Her specialties are general management, controlling and crisis management. E-mail: anna.zablocka-kluczka@ pwr.edu.pl

Agata Klaus-Rosińska, Ph.D. Eng., is Associate Professor at the Institute of Organization and Management, Faculty of Computer Science and Management, Wroclaw University of Technology (Poland). Dr. Klaus-Rosińska received her Ph.D. in management sciences at Wroclaw University of Technology. Her specialties are project management, managerial accounting and cost calculations. E-mail: agata.klaus@pwr.edu.pl

\section{REFERENCES}

1. Aubry, M., Hobbs, B., and Thuillier, D. (2007). A new framework for understanding organizational project management through the PMO, International Journal of Project Management 25 (2007), p. 328-336.

2. Aubry, M., Hobbs, B., and Thuillier, D. (2008). Organizational project management: An historical approach to the study of PMOs, International Journal of Project Management 26 (2008), p. 38-43.

3. Aubry, M., Müller, R., Hobbs, B., and Blomquist, T. (2010). Project management offices in transition, International Journal of Project Management 28 (2010), p. 766-778.

4. Avots, I. (1969). Why does project management fail? California Management Review 12, p. 77-82.

5. Camilleri, E. (2011). Project Success. Critical Factors and Behaviours, GOWER.

6. Espinasse, P. (2011). Full Costing: An introduction and lessons learnt in UK and Finland, EUIMA - Full Costing Project - Country Workshop: Poland Universities Implementing Full Costing (workshop documentation), p. 12-14.

7. Garel, G. (2013). A history of project management models: From pre-models to the standard models, International Journal of Project Management 31 (2013), p. 663-669.

8. Grzech, A., Klaus-Rosińska, A., Pawełczak, R., and Zabłocka-Kluczka A. (2011). Koncepcja Centrum Zarządzania Projektami Uczelni, Raport Politechniki Wrocławskiej.

9. Heising, W. (2012). The integration of ideation and project portfolio management - A key factor for sustainable success, International Journal of Project Management 30 (2012), p. 582-595.

10. Hobbs, B., Aubry, M., and Thuillier, D. (2008). The project management office as an organizational innovation, International Journal of Project Management 26 (2008), p. 547-555.

11. Hyvari, I. (2006). Project management effectiveness in project-oriented business organizations, International Journal of Project Management 24 (2006), p. 216-225. 
12. IDS Scheer (2010). Analiza i optymalizacja procesów podstawowych i wspomagających w działalności Uczelni, Raport Politechniki Wrocławskiej.

13. Kerzner, H. (2003). Strategic planning for a project office, Project Management Journal 34 (2), p. 13-25.

14. Liu, L. L. and Yetton, P. Y. (2007). The contingent effects on project performance of conducting project reviews and deploying project management offices, IEEE Transactions on Engineering Management 54 (4), p. 789-799.

15. Munns, A. K. and Bjeirmi, B. F. (1996). The role of project management in achieving project success, International Journal of Project Management, Vol. 14, No. 2, pp. 81-87.

16. Naveh, E. (2007). Formality and discretion in successful R\&D projects, Journal of Operations Management, Vol. 25, Issue 1, p. 110-125.

17. Pemsel, S. and Wiewiora, A. (2013). Project management office a knowledge broker in project-based organization, International Journal of Project Management 31 (2013), p. 31-42.

18. Ratnatunga J. and Waldmann E. (2010). Transparent Costing: Has the emperor got clothes?, Accounting Forum 34 (2010), p. 196-210.

19. Soderlund, J. (2004). Building theories of project management: past research, question for the future, International Journal of Project Management 22 (2004), p. 183-191.

20. Trocki, M., Grucza, B., and Ogonek, K. (2004). Zarządzanie projektami, Polskie Wydawnictwo Ekonomiczne, Warszawa.

21. Wageman, S. W. (2004). Risk Management on Research and Development Projects, AACE International Transactions RISK.07.

22. Wanga, J., Linb, W., and Huangc, Y. (2010). A performance-oriented risk management framework for innovative R\&D projects, http://www.researchgate.net/publication/229043719_A_performance-

oriented_risk_management_framework_for_innovative_RD_projects. 